\title{
Intercultural Communication and English Education
}

\author{
L.Shi \\ QiLu Normal University, Shandong Provence, P.R. China
}

\begin{abstract}
With the increase of global communication, people need to master broaden knowledge about the world to deal with different situations. The purpose of English education is not only to cultivate students' English grammar competence but also to cultivate students' intercultural communication competence. After introducing intercultural communication and intercultural communication competence, this paper states the current situation of English education in China which includes the analysis of the reasons for the lack of intercultural communication competence, and it also puts forward some strategies for cultivating students' intercultural communication competence in English education.
\end{abstract}

KEYWORD: Intercultural communication; Intercultural communication competence; English education

\section{INTRODUCTION}

Different country has different culture. Since people from different culture have different values, customs and behavior style, it is indispensable for people to go through their own culture and learn to accept others' in order to decrease the conflicts among them. With development of globalization, international exchanges have become more frequent and more and more people have been realizing the importance of intercultural communication. Intercultural communication is communication between people whose culture perceptions and symbol systems are distinct enough to alert the communication event. Obviously, successful intercultural communication is realized through language. Culture is the soil of language, while language is a mirror of culture. The intercultural communication and English education are closely related to each other. Students, especially Englishmajor students, should learn more about interculture. Meanwhile, as educators, it is necessary to cultivate students' intercultural communication competence in English education and encourage them to involve in more intercultural communication.

\section{INTERCULTURAL COMMUNICATION}

\subsection{Culture and language}

It is universally acknowledged that culture and language are closely inter-connected. (Kramsch,
1998) Brembeck (1977) had ever said humorously that to know another's language and not his culture was a very good way to make a fluent fool of one's self. Culture has several components, one of which is language. As a mirror of culture, language is strongly influenced and shaped by culture. Language is the carrier and container of culture and also exerts its influence on culture. To be concise, language is a part of culture, reflects culture and makes it come down from generation to generation. On the other hand, culture embraces language and sets a context in which the language occurs. Understanding the inextricable relationship between language and culture has significant pedagogical implications for the teaching profession. Since they are intricately interwoven, it is impossible for learners to master a foreign language without knowing the norms and values of the target culture.

\subsection{Culture and communication}

Culture and communication are interwoven so closely that Hall (1959) maintains that culture is communication and communication is culture. On the one hand, culture is learned and transmitted from one generation to another through communication. We acquire our membership of culture mainly through socialization with other members of our culture. On the other hand, without sharing and understanding of some common elements in culture, no communication will occur. Whether communication is successful or not depends greatly on whether the participants have some similar 
cultural background, knowledge and experiences. Understanding the close relationship between culture and communication is crucial to intercultural communication because it is through the influence of culture that people learn to communicate.

\subsection{Intercultural communication}

Intercultural communication is communication between people with different backgrounds, symbols systems and cultural perceptions. According to Karlfried Knapp (1987), intercultural communication is the interpersonal interaction between members of different groups, the groups differ from each other in respect of the knowledge shared by their members and in respect of their linguistic forms of symbolic behavior. The major task of intercultural communication is "to find out how culture and communication condition and transform one to another that real understanding can be achieved among intercultural interactions. (Song, 2004)

\subsection{Intercultural communication competence}

In Longman Dictionary of Language Teaching \& Applied Linguistics (2003), intercultural communication competence is defined as the ability not only to apply the grammatical rules of a language in order to form grammatically correct sentences but also to know when and where to use these sentences and to whom. Brown (2001) considers that intercultural communication competence is the competence that enables learners to convey and to interpret messages and to negotiate meanings interpersonally within specific contexts, including intercultural contexts. Compared with communication competence, intercultural communication competence can be conceived of as the ability to negotiate cultural meanings and to appropriately execute effective communication behaviors that recognize each other's multiple identities in a specific environment.

\section{ENGLISH EDUCATION IN CHINA}

\subsection{The current situation of English education}

English, as a foreign language, plays an important role in Chinese education. Most students begin to learn English in primary school. Both students and English teachers focus on English examinations and spend much time on vocabulary and grammar. As a result, some Chinese students, who can produce grammatically correct sentences, don't know how to use them properly in different social contexts. Some undergraduates or postgraduates working in joint ventures could not read simple telex or correspondence, and also failed to communicate properly with native English speakers. (Jing, 1999) Early in 1996, the former Vice-Premier Lanqing Li pointed out that the method adopted in teaching foreign languages in our country is time-consuming, energy-consuming but inefficient. A majority of students cannot read original foreign language books with ease even after eight or twelve years of foreign language study. Especially, they are poor in listening and speaking, making it very difficult for them to communicate with foreigners. This indicates that the foreign language teaching in our country is not effective and satisfactory. (Li, 1996) Apart from students' unsatisfactory performance in listening, speaking and reading, their pragmatic failures in the context of intercultural communication make up the most mistakes. One of the most important reasons is the lack of intercultural communication competence in dealing with intercultural exchanges effectively.

\subsection{Reasons for the lack of international communication competence}

There are many reasons that result in the lack of international communication competence.

First, traditional teaching methods cannot meet the students' demand for intercultural communication competence. For a long time in China, teaching methods are grammar-oriented and exam-oriented. Teachers emphasize the importance of grammar, vocabulary and pronunciation and encourage students to pass various exams or to get various certificates. Teachers pay more attention to students' marks and students have less chance to practice English in the class. As a result, students have good grades but lack of the ability to use language appropriately and effectively in intercultural communication.

Second, teachers' ability is limited in intercultural communication. Most English teachers are trained in Chinese environment, they don't' have enough experience and knowledge in intercultural communication. It is not easy for teachers to get a chance to go abroad to learn and experience different culture. On the other hand, most teachers are accustomed to traditional teaching methods and some of them who are confident of their own ability are not willing to change their teaching methods.

Third, students' initiative and effectiveness are insufficient. It is important for students to be equipped with enough initiative. Initiative involves that students have the motivation and they want to study. In traditional English education, many students are forced to learn and accept knowledge, and they have no chance to follow their own mind. After a while, they lost their passion to learn little by little. While effectiveness stresses that students need to decide what should be learned, from which they can benefit. Only the right choice can lead a better learning journey. Due to traditional teaching pattern, 
which is always teacher-centered, the students just need to make notes without thinking or questioning the answers. Therefore, students are lack of initiative and ability of deciding the effectiveness of knowledge and they are inclined to use wrong or ineffective expressions during intercultural communication.

\section{STRATEGIES FOR CULTIVATING INTERCULTURAL COMMUNICATION COMPETENCE IN ENGLISH EDUCATION}

Intercultural communication competence plays an important role in English education. Owing to the lack of intercultural communication competence, students may have the experience of making mistakes in intercultural communication, which may cause offence and arouse hostility from native people. With the culture being introduced to the students, they can understand and master the using of English. Classroom is an important place to study different cultures and communicate with others. Therefore, it is worthwhile to make good use of classroom. To cultivate students' intercultural communication competence, we can start from the teacher.

\subsection{Improving teachers' intercultural awareness}

First, teachers should change their teaching concepts and traditional teaching methods. It is important to realize that the class should be student-centered. Teachers should make enough chances to encourage students to take part in different intercultural communication contexts and set different situations to encourage students speak English both in and out of class. On the other hand, English education is not only grammar-oriented. Culture is as important as grammar in English education. Teachers should pay more attention to culture and adopt new teaching method to cultivate students' intercultural communication competence.

Second, teachers should pay much attention to the relation between culture and teaching, and then improve their own quality and arouse students' interests in learning. Teachers should be equipped with enough other cultures, such as their history, social system and values. If possible, teachers should be involved in real western life and have their own experience in intercultural communication. Moreover, teachers should have a life-long study and provide students with some updated information.

\subsection{Cultivating students' intercultural awareness}

First, students should identify their attitudes, prejudices, opinions, likes and dislikes. They should have a correct attitude of learning both native and target culture. Second, it is not only the study of foreign culture, but also the spread of native culture. Lacking of native culture will have a great effect on intercultural communication. Students need not only to express foreign cultures in English, but also to use English to introduce Chinese culture to the world.

\subsection{Learning to be open and flexible}

To be open means to accept change and absorb new ideas. To be flexible means using various ways to communicate. Only by keeping an open mind can students absorb new ideas and realize intercultural communication successfully. In intercultural communication, students will encounter people from different cultural background. They need not only being tolerant of others but also learning from others. So students should be open to the outlooks and flexible to different culture by adapting their own communication style to western communication style. Facing with cultural differences, students should respect and see them objectively, and realize that different cultures will enrich the world instead of creating conflicts. If we can appreciate similarities and respect differences of two cultures, we are able to learn new ways of seeing and experiencing in life.

\subsection{Making use of modern technology}

Modern network technology is playing a more and more important role in intercultural communication. The internet makes the world closer and we can encounter people all over the world within one minute. However, with the influence of our mother tongue, people are inclined to follow their own customs. Therefore, culture conflicts can happen everywhere. In order to reduce the influence of negative transfer of mother tongue, both teachers and students can make good use of modern technology, such as watching videos about other cultures, chatting with friends from different country on the internet. There are some software, such as QQ, skype and facebook, which provide us with more chances to communicate with friends all over the world to learn different culture then improve our intercultural communication competence. What's more, multi-media in classroom is also good chance to have a general idea on the target language.

\section{CONCLUSION}

Language is the mirror of culture. English education is not only for the application of the linguistic rules but also a kind of culture knowledge and awareness. Both teachers and students should focus on intercultural communication. Teachers play an important role in cultivation of intercultural communication competence in English education. It 
is necessary for teachers to find a way to lead students to develop a good habit of learning. To improve students' intercultural communication competence needs not only teachers' effort but also the students themselves, which is the most important one. In a word, culture is as important as language code in English education, only with excellent intercultural communication competence, can we integrate into the world better and spread our culture better.

\section{REFERENCES}

[1] Brembeck, W. 1977. The Development and Teaching of a College Course in Intercultural Communication. In Reading in Intercultural Communication. SIETARUniversity of Pitsburgh.
[2] Brown, H. D. 2001. Principles of Language Learning and Teaching. Beijing: Foreign Language Teaching and Researching Press.

[3] Hall, E.T. 1959. The Silent Language. New York: Anchor Books.

[4] Jing, S. H. March 10, 1999. English Teaching is A Pot of Water Never Boiled? ---The Review of English Teaching. China Youth Daily.

[5] Karlfried, K. 1987. Analyzing Intercultural Communication. New York: Water de Gruyter.

[6] Kramsch, C. 1998. Context and Culture in Language Teaching. Shanghai: Shanghai Foreign Language Education Press.

[7] Li, L. Q. October 5, 1996. Changing Foreign Language Teaching Method to Improve Foreign Language Teaching. People's Education.

[8] Song, L. 2004. Gateway to Intercultural Communication. Harbin: Harbin Institute of Technology Press. 